\title{
BIMODÁLIS (KÉTCSÚCSÚ) TERMÉKENYSÉGI GÖRBE MAGYARORSZÁGON: LEÍRÓ EREDMÉNYEK ÉS LEHETSÉGES OKOK
}

\section{Kapitány Balázs}

\section{ÖSSZEFOGLALÓ}

A termékenység időbeni lefutásának, a termékenységi görbe (fertility curve) mintázatának és változásainak vizsgálata évtizedek óta a nemzetközi és a hazai demográfia klasszikus tárgyát alkotja. Emiatt már régóta ismert az a tény is, hogy egyes ritka, speciális esetekben előfordul, hogy egy társadalomban - jellemzően egy átmeneti időszakban - két termékenységi csúccsal rendelkező (bimodális) termékenységi görbe alakul ki. A friss magyarországi adatok arra utalnak, hogy az utóbbi években, hazánkban is kialakult ez a bimodális eloszlású termékenységi görbe. A jelenség esetleges társadalom- és népesedéspolitikai jelentősége miatt indokoltnak érezzük a bimodális termékenységi mintázatok kapcsán született szakirodalom vázlatos bemutatását és a hazai eredmények részletesebb vizsgálatát. Eredményeink szerint a jelenség kialakulása feltehetően a 2011-2016 között, Magyarországon megfigyelhető mintegy 20\%-os, társadalmilag, demográfiailag meglehetősen szelektív termékenységemelkedéshez köthető, mintegy annak mellékhatása.

Tárgyszavak: termékenységi görbe, termékenységi átmenet, bimodalitás

Kapitány Balázs, KSH Népességtudományi Kutatóintézet

E-mail:kapitany@demografia.hu 


\section{A TERMÉKENYSÉGI GÖRBE FOGALMA, TÍPUSAI}

A termékenységi görbe fogalmát a demográfiában a termékenység női életkor szerinti lefutásának jellemzésére használjuk, oly módon, hogy a vízszintes tengelyen ábrázoljuk a (női) életkort, míg a függőleges tengelyen az adott korban jellemző gyermekvállalási kedvet (jellemzően egy nőre számítva, ezrelékben megadva'). A termékenységi görbe tehát gyűjtőfogalom, amely bemutatható különféle alpopulációk kapcsán, illetve kiszámolható különféle mérőszámok felhasználásával.

A termékenységi görbe két fő formája a keresztmetszeti (naptári éves, period) és a kohorsz- (cohort) típusú. A bemutatást a keresztmetszeti görbével kezdjük, mivel ennek használata az általános, nyilván nem függetlenül attól, hogy előálítása kevésbe adatigényes, hiszen egyetlen naptári év adataiból előállitható, értelmezése egyszerübb. A keresztmetszeti termékenységi görbe kiszámításához egyfelől szükséges ismerni a női populáció koréves létszámát (pl. 2016-ban hány 32 éves betöltött életkorú nő élt Magyarországon²), másfelől az adott évi élveszületések eloszlását az anya betöltött életkora szerint (pl. 2016-ban hány olyan gyermek született Magyországon, akinek az édesanyja 32 éves volt). Ezen adatok alapján kiszámolható az egyes naptári évek esetén a korévenkénti gyermekvállalási kedv, amelyeket a termékenységi görbe ábrázol. Ez a termékenységi görbe jelenik meg azután például a demográfiai évkönyvekben 'ezer megfelelő nőre jutó élveszületés' címen. Mivel az egy adott naptári évre számolt teljes termékenységi arányszám (TTA, total fertility rate) a termékenységi görbéket is alkotó korspecifikus termékenységi arányszámokból képezhető, így a TTA nagysága lényegében megfeleltethető a görbe alatti terület nagyságának. Tehát a keresztmetszeti termékenységi görbe vizsgálatával az is megállapítható, hogy a termékenység növekedésének vagy éppen csökkenésének hátterében mely kor szerinti csoportok találhatók.

Magyarországon - sok fejlett országhoz hasonlóan - a demográfiai évkönyvekben publikált születésszámok értelemszerüen a teljes körü népmozgalmi adatgyűjtésből származnak, amely tartalmazza a szülő nő születésének idejét is. Az alapsokaság (2016-ban pontosan hány 32 éves nő is él Magyarországon) becsült nagysága viszont a népszámlálásokból továbbvezetett adatokból szár-

\footnotetext{
' Ez nem más, mint a korspecifikus termékenységi arányszám (age-specific fertility rate).

${ }^{2}$ A keresztmetszeti termékenységi adatok betöltött életkor szerinti arányszámai mindig az adott életkorú női népesség évközepi számára vonatkoznak.
} 
mazik, figyelembe véve az adott csoportban a népszámlálás óta bekövetkezett halálozásokat és nemzetközi vándorlásokat. Mivel utóbbi számbavétele sajnos nem teljes körü, így a továbbvezetett népességszám esetén számolhatunk bizonyos pontatlanságokkal. Például a tömeges, nem regisztrált kivándorlás miatt az alapsokaság tényleges nagysága feltehetően valamivel alacsonyabb, mint a továbbvezetett adat. A magyarországi továbbvezetési eljárás azonban nem általános, sok olyan - köztük fejlett - ország létezik, ahol nincs, vagy nem ilyen formában van népesség-továbbvezetés. Ezekben az országokban a népszámlálási évek környékén, a népszámlálási adatokból lehet megbecsülni a kockázati sokaságot.

A keresztmetszeti termékenységi görbék témánk szempontjából fontos, és igen gyakran használt alcsoportja a paritásspecifikus termékenységi görbék. Ezekben az esetekben csak egy adott sorszámú (jellemzően az első) gyermek a nő adott életkorában történő megszületésének esélyét ábrázoljuk. Ennek két fajtája létezik, a feltételes (az angol szakirodalom nem egységes: conditional fertility rate; exposure-specific birth rate; occurence rate, Type 1. rate) és nem feltételes (angolul unconditional rate, incidence rate, Type 2 rate is használatos). A feltételes termékenységi görbék esetén a kockázati sokaságot csak az adott paritáson lévő nők jelentik: vagyis pl. hány 32 éves gyermektelen nő vállalta első gyermekét 2016-ban. A nem feltételes termékenységi görbe esetén az alapsokaság nem korlátozott: a 32 éves nőknek - gyermekszámuktól függetlenül - összesen hány első gyermeke született 2016-ban. Mindkét altípus használatos, megvannak az előnyei és a hátrányai is. (Például a nem feltételes ráták értékei egyszerűen összeadva kiteszik a teljes termékenységi görbét.)

Természetesen termékenységi görbék más alsokaságokra is számolhatók. A kétcsúcsú termékenység kapcsán a szakirodalomban elsősorban házasságból és házasságon kívül született gyermekekre, vagy az anya iskolai végzettsége, esetleg rasszok, etnikumok szerint számolt görbék jelennek még meg. Minden ilyen esetben elvileg lehetséges feltételes és nem feltételes ráták számítása. A feltételes ráták alkalmazásának jellemzően az szab határt, hogy a becsléshez szükséges alapsokasági létszám nem ismert vagy csak igen nagy bizonytalansággal becsülhető. Magyarországon például a paritás-szerinti népesség-továbbvezetést a KSH végzi (így van becslésünk arra vonatkozóan, hogy például egy adott naptári évben hány kétgyermekes 32 éves nő él az országban), de az iskolai végzettség szerintit már nem. Így csak a népszámlálások (és a mikrocenzusok) éveiből ismerjük azt az adatot, hogy hány 32 éves diplomás nő alkotná egy feltételes ráta kiszámításához a kockázati sokaságot. 
A termékenységi görbék másik típusát a kohorsz típusú görbék jelentik. A keresztmetszeti jellegü görbék egy adott naptári évre vonatkoznak, így értelemszerüen nem egy valós, hanem mesterségesen létrehozott, a valóságban soha nem létező női generáció (ún. szintetikus kohorsz, synthetic cohort) termékenységét mutatják be. Egy keresztmetszeti görbe esetében például egy adott ábrán szereplő 20 és 32 éves kori korspecifikus arányszám értelemszerűen nem ugyanazon nők adataiból került kiszámításra. A x. naptári évre vonatkozó ábrán szereplő 22 éves nők 32 éves kori gyermekvállalási kedve majd az x+10. évre vonatkozó keresztmetszeti jellegü görbéből lenne valójában leolvasható. Ezzel szemben a kohorsz típusú termékenységi görbék nem egy adott naptári évre vonatkoznak, hanem (jellemzően) egy vagy több születési évjárat (például az 1983-ban született nők) adatait összesitik, azt mutatják be, hogy az adott évjárat 23, 24 stb. éves korában milyen eséllyel vállalt gyermeket. A kétcsúcsú termékenységi görbék nem csak keresztmetszeti, hanem kohorsz típusú görbék esetén is megfigyelhetők, bár az utóbbiak vizsgálata (vagy maga a jelenség is) lényegesen ritkább a szakirodalomban (példa rá: Burkimsher 2017). Jelen tanulmányban mi sem használunk kohorsz típusú görbéket.

\section{A TERMÉKENYSÉGI GÖRBE DEMOGRÁFIAI JELENTÖSÉGE, SPECIÁLIS FORMÁI}

A korspecifikus termékenységi arányszámokat tartalmazó görbék modellezése az 1930-as évektől a népességtudomány figyelmének középpontjában állt. Ezen görbék esetleges szabályszerüségének megismerése, modellezésének lehetősége a gyermekvállalási életkor szerinti lefutásának megismerésének ígéretével kecsegtetett a demográfusok számára, illetve a kérdés a matematikusok figyelmét is felkeltette. Hátha van valamilyen általánositható demográfiai szabályszerüsége a szülések életútbéli lefutásának, amely ezen görbék modellezésével feltárható? Az 1960-as évekre már teljesen nyilvánvalóvá vált, hogy ez egy illúzió, „a korspecifikus születési arányszámok leírásához nem létezik valamilyen egyszer s mindenkorra rögzített típusú modell” (Tekse 1965: 216).

Miközben a görbe modellezhetősége problémájának elméleti érdekessége csökkent, a kohorsz-komponens típusú népesség-előreszámítások kialakulásával a kérdés hirtelen gyakorlati szempontból lett érdekes. Ezen előreszámításokhoz módszertani okokból ugyanis nem csupán a jövőre vonatkozó 
általános termékenységi arányszámra kellett becslést adni, hanem korspecifikus termékenységi arányszámokra is, ez pedig más módon, mint valamiféle függvény illesztésével, bajosan lett volna megoldható. Vukovich György ezt már mintegy fél évszázada a következőképpen fogalmazta meg: „A termékenységi görbe alakja ugyanis - az elméleti problémákon túlmenően - igen fontosnak tünik a demográfiai gyakorlatban is [...] a népesség-elöreszámitások elvégzéséhez, mert a jövőbeli termékenység elörebecsült szintjeihez tartozó kor szerinti görbéket rendkívül nehéz, sőt gyakran csaknem lehetetlen megbecsülni. [...] az elöreszámitások során állandóan problémát okoz olyan görbetipusok meghatározása, amelyek az egyes évek korspecifikus termékenységi arányszámait megnyugtató módon meghatároznák” (Vukovich 1969: 65).

Emiatt aztán - kisebb-nagyobb lelkesedéssel - évtizedekig folyamatosan foglalkoztak a demográfusok ennek a gyakorlati feladatnak a megoldásán. Eközben tűnt fel, hogy bár az esetek túlnyomó többségében egyetlen csúccsal rendelkező görbékről van szó, még ez sem mondható általános szabálynak. Chandola és társai 1999-ben arra hívták fel a figyelmet, hogy az akkori legfrissebb adatokban az Egyesült Királyságban és Írországban a korai életkorban furcsa torzulás, egyfajta kidudorodás (bulge) figyelhető meg, amely miatt a korábban használatos modellek nem igazán képesek leírni a termékenységi görbét. Őket ez a kérdés elsősorban módszertani megközelítésből (modellezési és illesztési szempontból) érdekelte, de a modellezési megoldás keresése közben nyilván felmerült az okság kérdése is. A szerzők megítélése szerint a korai években megfigyelhető kidudorodás leginkább úgy modellezhető, ha nem egy, hanem két különböző alpopulációt feltételezünk, és ennek a két populációnak termékenységi görbéjét kombináljuk. Erre a célra konkrét modellt is javasoltak (Hadwiger mixture model). Az ő elképzelésükben ez (írországi és nagy-britanniai adatokon empirikusan tesztelt) két alpopuláció, a házas és nem házas populáció termékenységi görbéje. E szerint a termékenységi görbe korai szakaszaiban megfigyelhető kipúposodás oka a két országban a tinédzser termékenység viszonylag nagy aránya, amely szinte kizárólagosan házasságon kívüli születésekből adódik. Fontos hangsúlyozni, hogy Chandola és társai még nem kétcsúcsú termékenységi görbét fedeztek fel, hanem csak egy olyan kipúposodást a görbében, amely nem jelentett helyi maximumot. Ezt követően a termékenységi görbét modellező cikkek már rendszeresen foglalkoztak ezekkel a nem hagyományos görbékkel, de merőben csak olyan technicista szempontból, hogy ezek hogyan modellezhetők (pl. Peristera - Kostaki 2007, Bermúdez et al. 2012). 
1. ábra: A termékenységi görbék néhány típusa (illusztratív példák)

Special types (traditional, with bulge, bimodal) of age-specific fertility rates (illustration)

A. "Hagyományos" termékenységi görbe

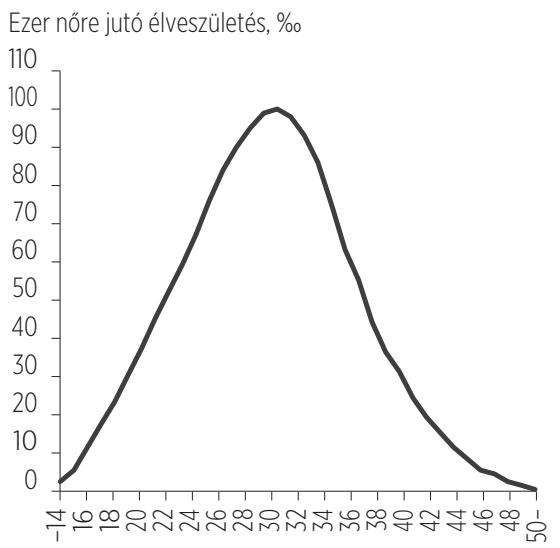

életkor, év
B. "Kidudorodó" termékenységi görbe

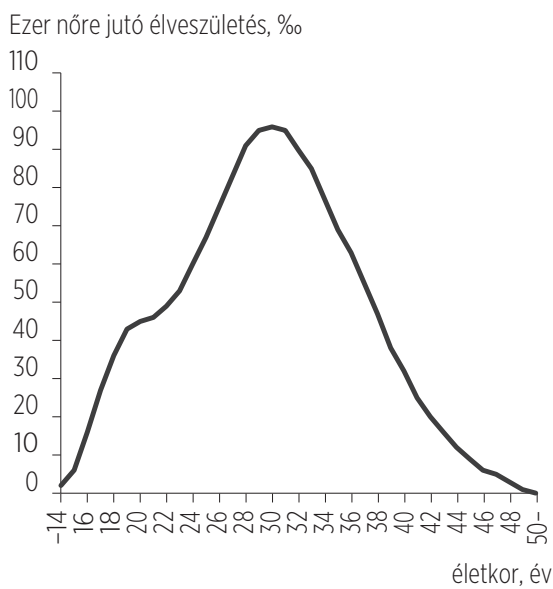

C. "Bimodális" termékenységi görbe

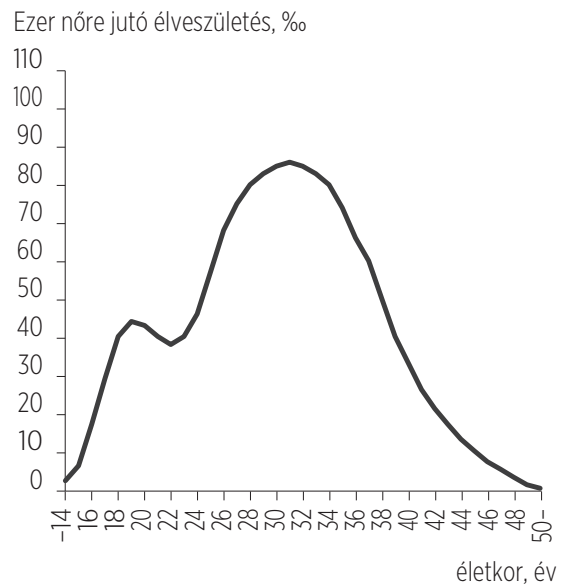

Ismereteim szerint az első olyan elemzést, amely már kifejezetten önmagában a bimodális termékenységi görbével foglalkozott, Sullivan publikálta 2005-ben a Demography folyóiratban. A szerző itt az Egyesült Államokban az 1990-es évek elején létrejövő, majd az ezredfordulóra gyakorlatilag megszűnő rejtett bimodális termékenységi görbe létére mutatott rá. Rejtettnek azért nevezem ezt a jelenséget, mert bár itt nemcsak „kidudorodásról” van szó, hanem tényleges kétcsúcsú termékenységi görbékről, de a bimodalitás kizárólag az első gyermek 
vállalása kapcsán, gyermektelen nőkre számolt (azaz feltételes) ráták esetén volt megfigyelhető, más esetekben - így a nem feltételes rátáknál - nem volt megfigyelhető. Sullivan egyfelől megalkotta a bimodalitás mértékének leírására használható merőszámokat (BIM, BIMalt), másfelől próbált magyarázatot találni a jelenség létrejöttére, illetve időlegességére. A görbéket kiszámolta etnikai csoportonként/rasszonként (fehérek, hispánok, afrikai amerikaiak), iskolai végzettség és családi állapot szerinti csoportonként is, és azt találta, hogy valójában az etnikumok szerinti eltérő termékenységi mintázatok az alkalmasabbak a jelenség okának megértésére. Elképzelése szerint az időleges bimodalitás létrejöttének az oka, hogy az 1990-es évek Amerikájában etnikai csoportok szerint eltérően zajlott le a termékenységi magatartás átalakulása (ez alatt lényegében az első gyermek vállalásának kitolódását értve). Míg a fehér és az afrikai amerikai csoportokban - noha más-más szinten -, de kitolódott az első gyermek vállalásának kora, addig a hispán csoportban ez mintegy egy évtizedig nem következett be. Ebben az időszakban jött létre a kétpólusú termékenységi görbe. Amikor a hispán csoport esetén is bekövetkezett a kitolódás, a bimodalitás megszünt.

Az egy társadalomban együtt élő etnikai, nemzetiségi csoportok eltérő termékenységi mintázata ezt követően több esetben felbukkan a bimodalitás okát kereső publikációkban. Burkhimser (2017) kohorsz típusú görbéket felhasználó, 22 országot összehasonlító, inkább leíró jellegű tanulmányában például elsősorban valamiféle - sok esetben átmeneti - társadalmi polarizáció jelentőségét veti fel, említve, hogy ez a polarizáció valamiféle etnikai dimenzió szerint is történhet. Svájc esetén például adatai szerint a bimodalitás kialakulásának oka a bevándorló és az őshonos lakosság eltérő termékenységi viselkedése. (Ugyanakkor hangsúlyozza az adatok megbízhatósági korlátait: egy ki- vagy bevándorlás által erőteljesen érintett társadalomban a ráta számolásához szükséges nevező mindig csak bizonytalanul becsülhető.³)

Lima és szerzőtársai (2017) négy latin-amerikai ország ezredfordulót követő termékenységi mintázatát vizsgálták, és elsősorban Chile és Uruguay esetén találtak erőteljes bimodális termékenységi mintát. Ennek oka - megítélésük szerint -, hogy miközben ezen országokban általában és jellemzően csökkent a termékenység, és egyben a társadalom jelentős részében kitolódott az első gyermekvállalás későbbi életkorra, addig az alacsony iskolázottságú nők körében

\footnotetext{
${ }^{3}$ Ez Magyarország esetén is felvethető. Természetesen nem zárható ki, hogy a visszaesés a 20-as életévek közepén a termékenységi görbében arra vezethető vissza, hogy alulmérjük a kivándorlást, vagy valójában kevesebb az alapsokaság, mint amelyet a népesség-továbbvezetés feltételez, vagy a cenzusok mérnek, hiszen a gyermeket nem vállalók egy része valójában már nem él Magyarországon.
} 
fennmaradt a korai gyermekvállalási mintázat (amely az esetek nagy részében nem tervezett és nem kivánt várandósság volt). Ezen kettősség feltételezett okaként a szerzők a latin-amerikai, különösen erőteljes társadalmi és jövedelmi egyenlőtlenségeket jelölik meg.

Korábban idézett, elsősorban leíró jellegű cikkében Burkhimser (2017) utal rá, hogy (kizárólag) kohorsz perspektívából az első gyermek vállalását vizsgálva több kelet-közép-európai országban is kialakult bimodalitás. Ez volt megfigyelhető az 1977-es születési kohorsz esetén Csehországban, Szlovéniában; az 1980-as születési kohorsz esetén Észtországban, Litvániában és Szlovákiában. Az említett kelet-közép-európai országok rejtett kohorszbimodalitása mögött azonban Limáéktól eltérő okokat feltételez Burkhimser. Úgy véli, hogy a kommunizmus bukását követően több országban a mintaváltás a korairól a kései gyermekvállalási magatartásra nem egységesen következett be. Egyes társadalmi csoportok tovább ragaszkodtak a korábbi korai mintához, míg mások esetén gyors volt az átalakulás. Így egy átmeneti periódusban néhány születési kohorszra jellemzővé vált a bimodalitás ebben a régióban.

\section{A TERMÉKENYSÉGI GÖRBÉK MAGYARORSZÁGON}

Az elemzésünk következő részében bemutatjuk a különböző fajtájú termékenységi görbéket Magyarországra. A görbék kiszámításához a következő adatforrásokat használtuk fel:

- Termékenységi adatok: születések száma az anyák életkora és élveszületéseinek száma, illetve legmagasabb befejezett iskolai végzettsége szerint bontva (a KSH népmozgalmi adatgyűjtése; az adatgyűjtés módszertanáról részletesen Id.: KSH 2013., az aktuális jogi háttérről Id.: 2016. évi CLV. törvény 28. és 30. § ).

- Népességadatok kor és gyermekszám szerint: a KSH által kor és gyerekszám szerint továbbvezetett női népességadat. (Forrás: KSH Demográfiai évkönyvek elektronikus melléklete, 1.2.7.-es táblák - A 15-49 éves nök születési év, korév és az élve született gyermekek száma szerint).

- Népességadatok kor, gyerekszám és iskolai végzettség szerint (a 2001. és 2011. évi népszámlálás és a 2016. évi mikrocenzus személyi szintű adatbázisa). 


\section{Keresztmetszeti általános termékenységi görbék}

A 2. ábrán négy kiválasztott naptári évre (1990, 2001, 2011, 2016) bemutatott termékenységi görbék célja az, hogy illusztrálják a hazai termékenységi magatartás átstrukturálódását a rendszerváltás éveitől napjainkig.

A rendszerváltáskori termékenységi görbén megfigyelhető, hogy ekkor még a női életkor növekedésével gyorsan nőtt a gyermekvállalás kedv, de csak 23-24 éves korig, amikor már elérte csúcspontját. 1990-ben ezer 23 éves nőből 160 szült gyermeket egy év alatt. Ezt az életkort követően már csökkent az adott korban vállalt gyermekek száma.

\section{2. ábra: Keresztmetszeti általános termékenységi görbék Magyarországon} Unconditional age-specific fertility rates in Hungary

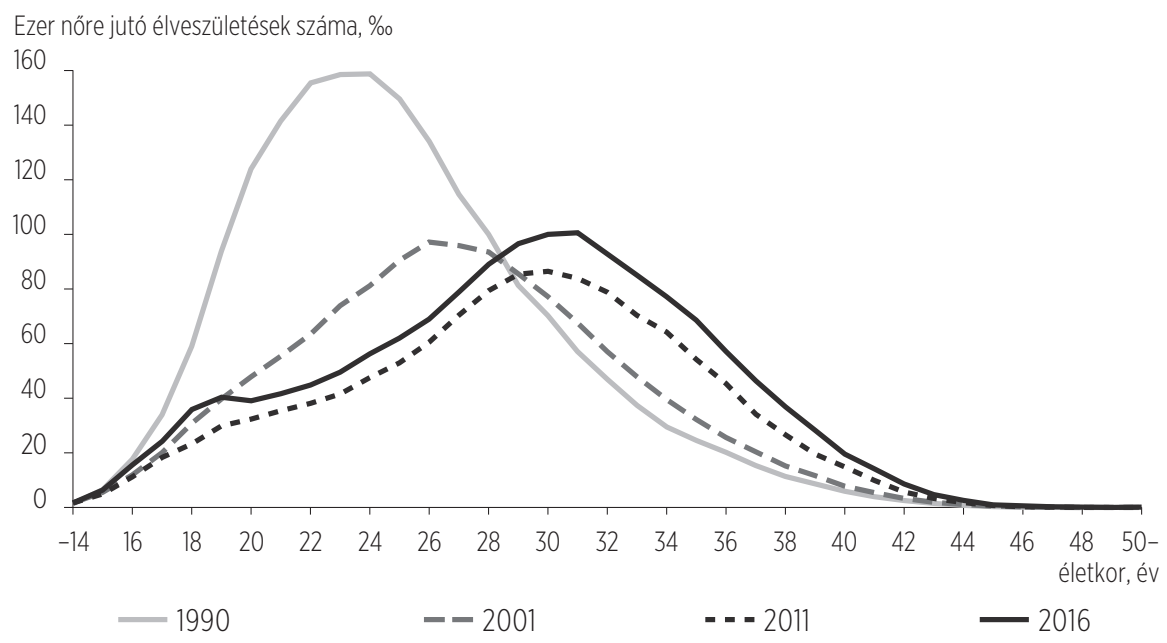

Forrás: KSH-adatok.

A koréves termékenység növekedésének tempója 1990-ben igen erőteljesen futott fel a nagykorúvá válást követően: 19 éves korig gyorsult, ezt követően már lassult a növekedési tempó (az ábrán a vonal meredeksége). A termékenység legnagyobb megugrása 1990-ben, 18 és 19 éves életkor között következett be: míg a 18 évesek 59, addig a 19 évesek 94\%o-e vállalt gyermeket .

A következő egy évtizedben drasztikusan visszaesett a termékenység, amely az ezredfordulót követően csúcspontját már 26 éves korban érte el, lényegesen

\footnotetext{
${ }^{4}$ Kor alatt itt és a következőkben is mindig a betöltött életkort, születés alatt az élveszületést értjük.
} 
alacsonyabb szinten, mint egy évtizeddel korábban (a 26 évesek 97\%o-e vállalt gyermeket). Témánk szempontjából legalább annyira érdekes, hogy a felfutás tempója lényegesen és látványosan lelassult, illetve a gyermekvállalási kedvben meglehetősen egyenletes, évi 7-10\%o-es növekedést figyelhetünk meg 16-26 éves kor között. Tehát az ezredfordulóra a gyermekvállalási kedv felfutásának tempója igencsak lelassult (Id. az ábrán a két görbe meredeksége közötti különbséget).

Az ezt követő évtizedben érdemben nem változott a gyermekvállalási kedv összesített mértéke (vagyis a teljes termékenységi arányszám), de egyértelműen tovább tolódott a gyermekvállalási kedv csúcsa (30 éves korra), és csökkent a felfutás tempója. 2011-ben a termékenységi görbében már megfigyelhetünk fiatal életkorban egy kis kicsúcsosodást: 15-19 éves kor között valamivel gyorsabban nőtt a gyermekvállalás kedv, mint az ezt követő 19-23 éves korban, amikor az emelkedés tempója kicsit laposodik, aztán 24-29 éves korban ismét meredekebbé válik a növekedés.

2011 és 2016 között jelentős termékenységemelkedés következett be, a teljes termékenységi arányszám 1,24-ról 1,49-ra emelkedett (vagyis nőtt a görbe által lefedett terület). A két ábra összevetésén látszik, hogy a gyermekvállalási kedv ez alatt a fél évtized alatt szinte minden életkorban nőtt, de nem egyenletesen. A legnagyobb növekedés a nagykorú, de még tizenéves (18-19 éves) kismamáknál, illetve a 30-as életévekben (pontosabban 29-38 éves korban) következett be. Ennek hatására a gyermekvállalási általános termékenységi görbe kétcsúcsúvá, bimodálissá vált: 2016-ban a 31 éves abszolút csúcs mellett 19 éves korban egy kisebb lokális csúcs is megfigyelhetővé vált. A gyermekvállalási kedv korai felfutásának a tempója 2011 és 2016 között egyértelmủen gyorsult: a görbe meredeksége nőtt, 19 éves korig hasonló az ezredfordulós értékhez. Ezt követően a gyermekvállalási kedv 19-22 éves korban gyakorlatilag stagnált, majd ismért nőni kezdett, de a növekedés tempója nem érte el a korábbi mértéket.

Az általános, nem paritásspecifikus termékenységi görbén megfigyelhető ilyen különleges eloszlás, bimodalitás igen ritka, ez a jelenség ugyanis jellemzően csak az első gyermekekre vonatkozó (és azon belül is sokszor vagy csak a feltételes, vagy éppen csak a nem feltételes) görbéken látható a szakirodalom szerint. Feltehetően, 2017-ben már a magyarországi általános termékenységi görbén sem lesz megfigyelhető. Azonban más országokhoz hasonlóan hazánkban is feltételezhető, hogy a bimodalitás jelensége látványosabb az első gyermekek esetén, ezért a következőben ezt vizsgáljuk meg. 


\section{Paritásspecifikus nem feltételes termékenységi görbék}

A nem feltételes paritásspecifikus termékenységi görbék lényegében az előző görbe felbontását jelentik. Kumulatívan ábrázolva ki is adják az általános nem paritásspecifikus termékenységi görbét (3a. és 3b. ábra).

3.a-b. ábra: Magyarországi, paritásspecifikus nem feltételes termékenységi görbék (A) kumulatív és (B) hagyományos módon ábrázolva, 2016

Unconditional age-specific fertility rates by parity sketched in (A) cumulative and (B) traditional way

A. "Kumulatív" termékenységi görbe

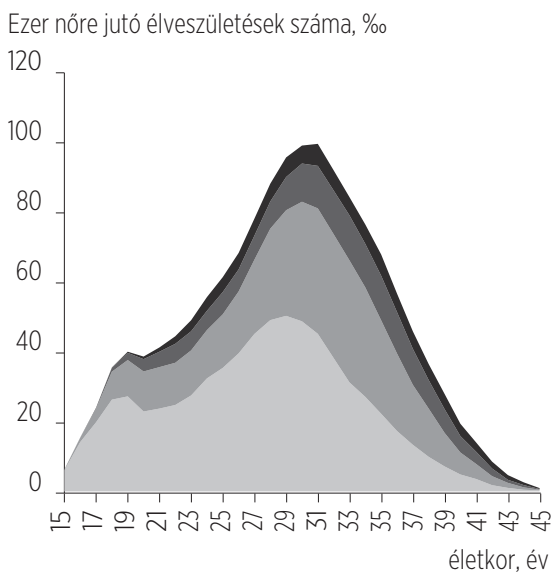

- Első élveszületés

— 3. élveszületés

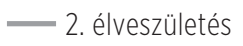

- 4. és többedik élveszületés
B. "Hagyományos" termékenységi görbe

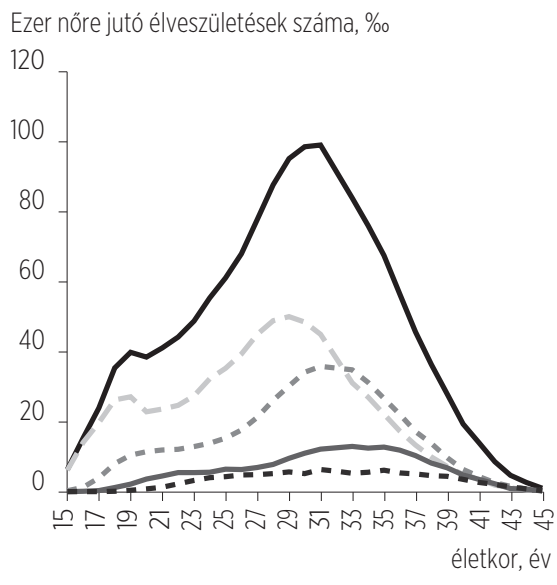

— Összes élveszületés - - Első élveszületés

$=-=2$. élveszületés - 3. élveszületés

- - 4. és többedik élveszületés

Forrás: KSH-adatok.

Az ábrák illusztrálják, hogy - nem meglepő módon - az általános görbén 2016-ban megfigyelhető bimodalitás elsődleges oka az első gyermek vállalásának bimodalitása volt. Ez a kétcsúcsúság az első gyermekek esetén sokkal látványosabb, kiegyenlítettebb, hiszen a 31 éves életkorban megfigyelhető általános termékenységi csúcs esetén jelentős, részben már a többedik gyermekek vállalásáról van szó. Az első gyermek vállalása esetén a második csúcs 29 éves korban következik be. Míg az első gyermekvállalások esetén az első életkori csúcs értéke 28, a másodiké 51\%o.

Ugyanakkor feltűnő, hogy a második gyermekek vállalása esetén is meglehetősen szabálytalan eloszlás alakult ki 2016-ban. Bár a nem feltételes 
görbék esetén bimodalitásról nem beszélhetünk, de ennek ellenére elég egyértelmű, hogy a korai felfutást egy hosszabb stagnáló szakasz követi, 20-23 éves kor között lényegében változatlan, 12\%o-es valószínúsége figyelhető meg a második gyermek megszületésének.

Érdemes megvizsgálni, Magyarországon mióta áll fent ez a helyzet, mióta bimodális az első gyermek vállalását leíró termékenységi görbe (4. ábra). Ha adott naptári évekre kiszámoljuk a görbét, megfigyelhető, hogy bár minimális mértékben, de már 2012-ben kialakult a kétpólusú lefutás: a 20 évesek körében az első gyermek vállalásának esélye már ekkor valamelyest meghaladta a 21 és a 22 évesekét. Ezt követően minden évben egyre erőteljesebben megfigyelhető a bimodalitás egészen 2016-ig. A 2017-es végleges adatok még nem ismertek, de az előzetes eredmények arra utalnak, hogy bár 2016-osnál lényegesen gyengébb mértékben, de még 2017-ben is kétpólusú volt az első gyermek vállalását jelző nem feltételes termékenységi görbe. (A 19 éves nők legalábbis 2017-ben is több első gyermeket vállaltak, mint a 20 évesek.) Összességében, tehát már legalább fél évtizedre fennáll a jelenség.

\section{4. ábra. Nem feltételes termékenységi görbék - első gyermek}

Unconditional age-specific fertility rates for birth order 1

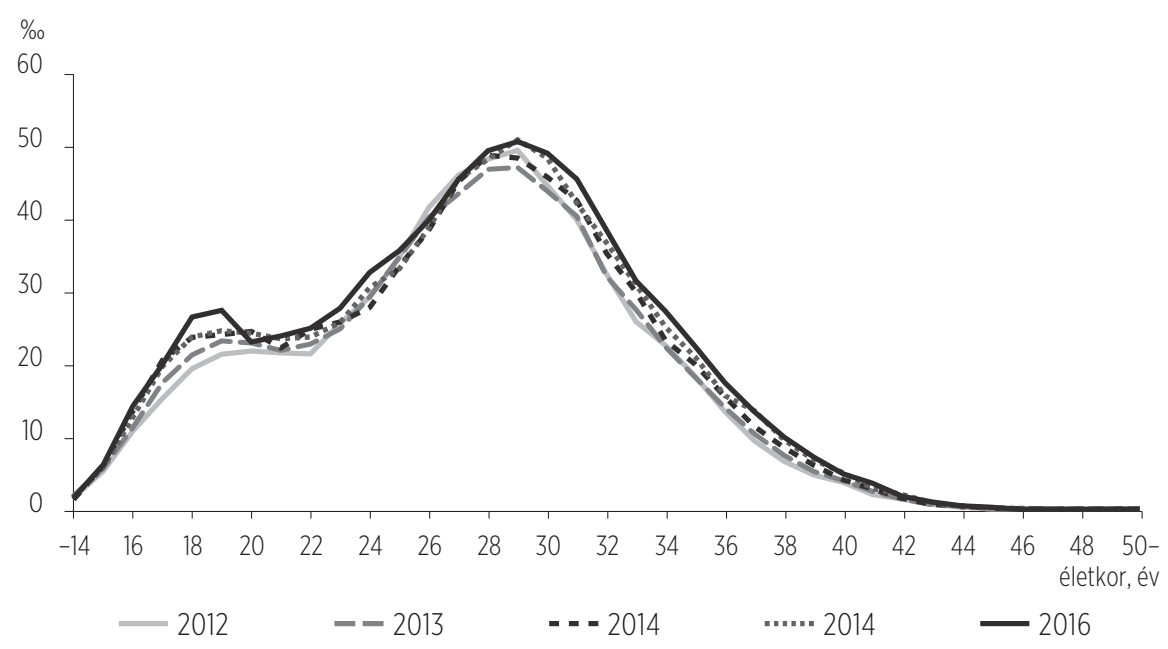

Forrás: KSH-adatok.

Kérdés, hogy ez az első gyermek vállalása kapcsán 2012-től megfigyelhető kétpólusúság Magyarországon mennyire tekinthető erősnek, nem csupán a termékenység valamiféle véletlenszerủ természetes, nem trendszerü 
ingadozásának a következménye. A Sullivan (2005) által alkotott BIM-mérőszám - megalkotója szerint legalábbis - többfunkciós: egyszerre alkalmas a jelenség leírására, illetve statisztikai szignifikanciájának tesztelésére is. Képzésének lényege, hogy a termékenységi görbét alkotó konkrét koréves értékeket egyre növekvő számú évből számolt mozgó átlaggal helyettesítjük, ezzel gyakorlatilag elsimítjuk a görbe kisebb ingadozását. Ahány éves mozgóátlagot kell vennünk ahhoz, hogy a bimodalitás megszűnjön, akkora értéket vesz fel az adott évre számolt BIMmutató. Sullivan szerint a 4-es vagy annál nagyobb BIM-érték már egyértelmüen azt jelenti, hogy erőteljes bimodalitásról beszélhetünk. Magyarországon az első gyermekre számolt nem feltételes termékenységi adatok esetén a BIM-mutató mértéke 2013-ban érte el 4-es értéket, 2014-ben is 4-es, 2015-2016-ban pedig 5-ös értéket vett fel. Ez alapján legalább olyan négyéves időszakról beszélhetünk, amikor az első gyermekvállalás kapcsán a bimodalitás egyértelmüen létezik hazánkban.

Érdemes a nagyobb paritásokon is megvizsgálni a nem feltételes termékenységi görbéket. Az áttekinthetőség miatt a következő ábrákban a bimodalitás megjelenése előtti utolsó (2011-es) év adatait vetjük össze 2016-os adatokkal (5.a-b. ábra). Ez az összehasonlítás azért is érdekes, mert ahogy már korábban is hangsúlyoztuk, pont ebben az időszakban nemcsak a bimodalitás alakult ki, hanem a termékenység is jelentősen emelkedett Magyarországon (a TTA értéke 2011-ben 1,23, 2016-ban 1,49 volt).

A második gyermek kapcsán látszik, hogy a növekedés hasonló mintázatú, mint az első gyermek esetén: a második gyermek megszületésének esélye 20 és 31-33 éves kor között átlag felett, míg a húszas életévekben mérsékelten nőtt. Ennek a nem egyenletes növekedésnek a következménye lett az a második gyermekek vállalása esetén megfigyelhető meglehetősen szabálytalan eloszlás, amelyet már korábban is hangsúlyoztunk.

Harmadik és többedik gyermekek esetén szintén nőtt a gyermekvállalási kedv, arányát tekintve ez a növekedés meglehetősen erőteljes, csaknem egyötödös volt. Ez az emelkedés viszont teljesen más életkori profilt mutat, kizárólag a 23 éves és idősebb, ezen belül is a 29-37 éves anyák esetén figyelhető meg.

Tehát a termékenység görbékből látható, hogy a 2011 és 2016 közötti termékenységnövekedés minden vizsgált paritás szerinti csoportban hasonló nagyságrendű (20\% körüli) volt, de ennek a növekedésnek más volt az életkori profilja az egyes gyermekszám szerinti csoportokban. Míg az első és a második gyermekek esetén a növekedés kétpólusú volt, addig a harmadik és többedik gyermekek vállalása kizárólag idősebb korban vált gyakoribbá. Ez utóbbi jelenség talán nem független egyes, a harmadik gyermekek 
vállalását erőteljesen preferáló intézkedések társadalmi célzottságától. (Míg az első és a második gyermek után járó adókedvezményt szinte minden, akár fiatal és alacsony munkajövedelmü család is teljes egészében igénybe tudja venni, addig ez nem mondható el a három- vagy többgyermekesek adókedvezményéről.)

5.a-b. ábra. Nem feltételes termékenységi görbék - (A) második gyermek, (B) harmadik és többedik gyermek

Unconditional age-specific fertility rates for $(A)$ birth order 2 and $(B)$ birth order $3+$
A. "Második gyermek"
B. "Harmadik és többedik gyermek"
termékenységi görbe termékenységi görbe

Ezer nöre jutó élveszületések száma, \%

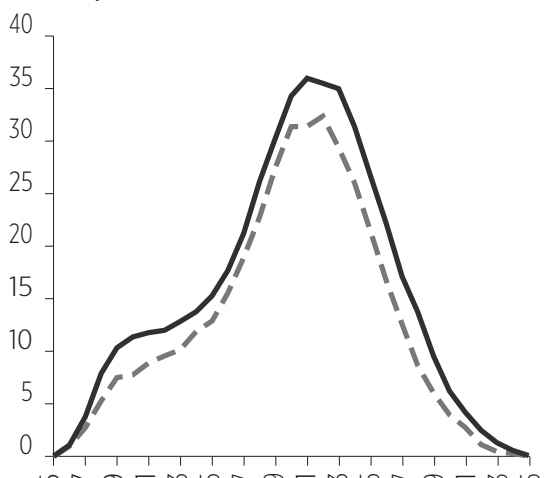

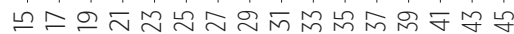
életkor, év

$--2001$

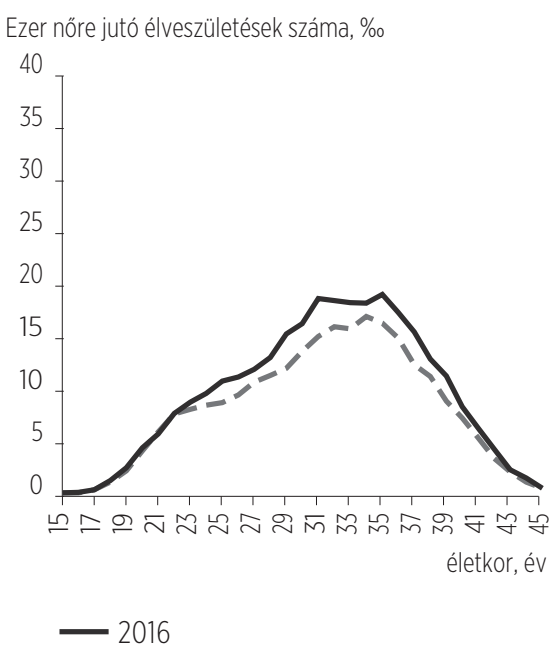

Forrás: KSH-adatok.

\section{Paritásspecifikus feltételes termékenységi görbék}

Talán valamivel nehezebben értelmezhető, de bizonyos szempontból többet mondó ábrákat kapunk, ha az első gyermek vállalása kapcsán feltételes termékenységi görbéket számolunk, vagyis a nevezőben nem az összes adott korú nőt, hanem csak az n-1 paritáson szereplőket vesszük (6. ábra). ${ }^{5}$

\footnotetext{
${ }^{5}$ Látható ez a megközelítés nem számol az ikerszülésekkel. Arányuk azonban olyan alacsony, hogy komoly torzitást nem jelentek az adatokban.
} 
Ezt a megközelítést használva, az első gyermekek arányát csak az adott korú gyermektelen nők számával vetjük össze. Ebben az esetben értelemszerűen a termékenységi görbén megfigyelhető második csúcs lényegesen nagyobbnak tűnik az elsőhöz képest, hiszen a harmincas életévei elején a nők egy jelentős része (mintegy 40\%-a) ekkorra már megszülte első gyermekét, így a gyermektelenekhez viszonyítva lényegesen nagyobb az első gyermek vállalásának esélye. Míg 2016-ban ezer 29 éves nőből mintegy 50 vállalt gyermeket, addig ezer 29 éves gyermektelen nőből mintegy 95. A bimodalitás ennek ellenére elég egyértelműen megfigyelhető.

6. ábra. Első gyermekre számolt feltételes termékenységi görbe, 2016 Conditional age-specific fertility rate for birth order 1

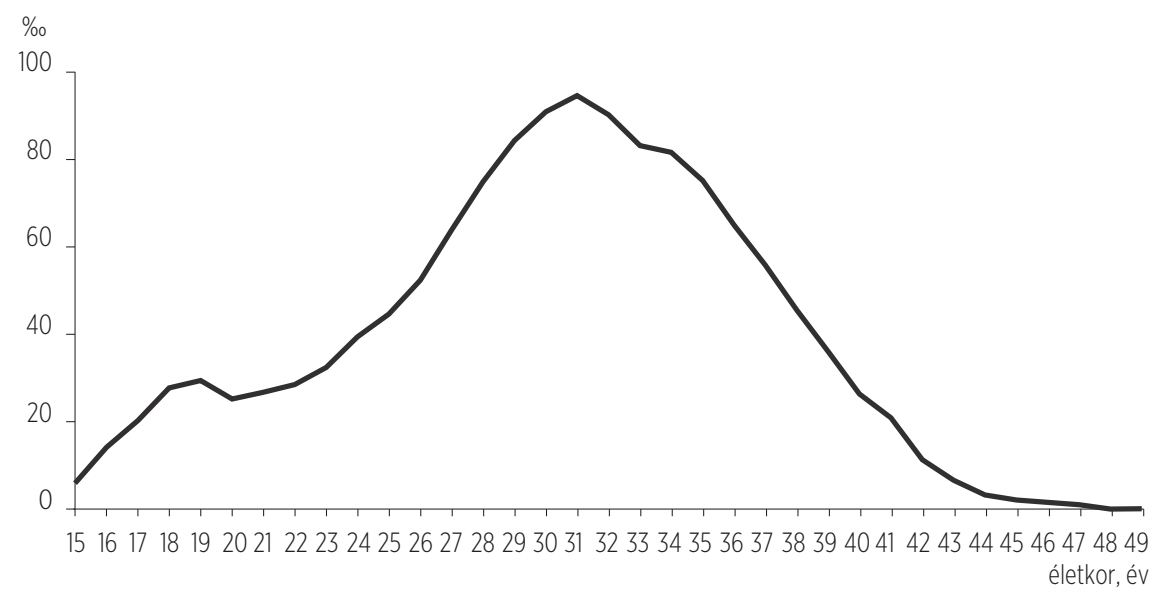

Forrás: KSH-adatok.

Igen érdekes képet kapunk, ha az egygyermekes nők arányát vetjük össze a született második gyermekek számával, ugyanis - a feltételes görbe esetén - itt egyértelmű bimodalitás figyelhető meg (7.a. ábra). A 10-es életévek végén, a 20-as életévek elején még elég kevés nő vállalja első gyermekét. Ezen fiatal, egygyermekes nők azonban igen jó eséllyel „dupláznak”, vagyis nagy arányban születik meg hamarosan az első testvér is. Ezt jól érzékelteti, hogy ezer 18-19 éves egygyermekes nő közül évente 180 vállal második gyermeket. Ezt követően viszont csökken az egygyermekesek gyermekvállalási kedve a 20-as életévek közepéig, amikor is 28-33 éves korban újabb, mérsékeltebb emelkedés figyelhető meg. 
7.a-b. ábra. Feltételes termékenyégi görbe, 2016 - (A) második gyermek, (B) harmadik és többedik gyermek

Conditional age-specific fertility rates for (A) birth order 2 and (B) birth order $3+$

A. "Második gyermek" termékenységi görbe
B. "Harmadik és többedik gyermek" termékenységi görbe
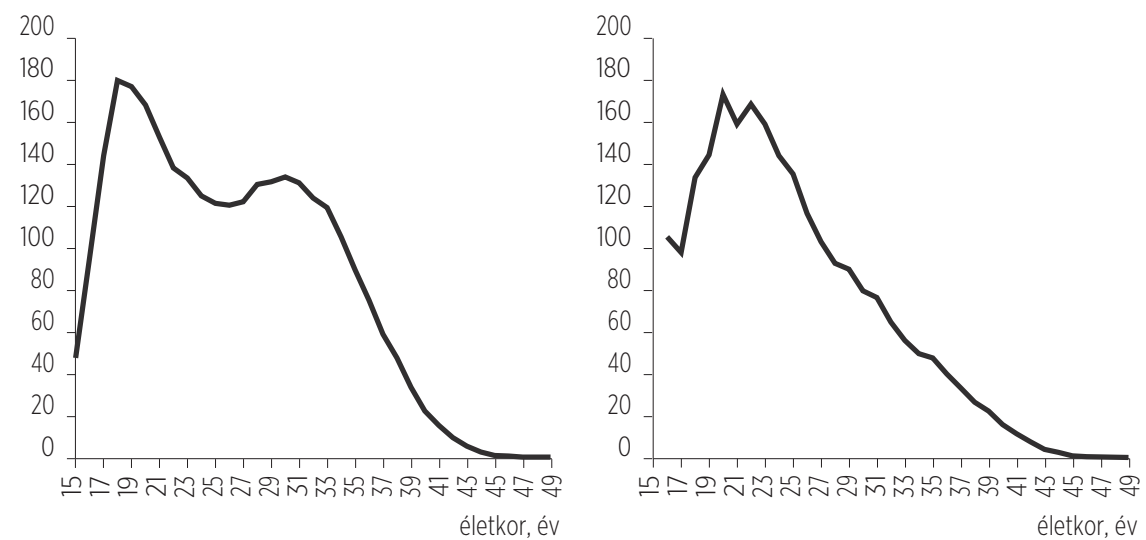

Forrás: KSH-adatok.

Ha megvizsgáljuk, hogy testvérüket mennyi idővel követve születnek meg második gyermekek az anya korának függvényében (8. ábra), azt tapasztaljuk, hogy míg a fiatal kismamákra jellemző volt a nagyon gyors, két éven belüli „duplázás”, addig a 30 körüli anyák esély feletti arányban vállalták célzottan 2 és 3 év között a kistestvért. Tehát a kétgyermekes nők feltételes termékenységi görbéjének második kiemelkedése mögött jellemzően nem az az ok, hogy a jóval korábban első gyermeküket vállalóknak a 30. életév környékén valamiért ismét „megjött a kedvük” a kistestvér vállalásához, hanem az, hogy a 30. életév környékén első gyermeküket vállalók a néhány évvel fiatalabbaknál ismét nagyobb arányban „dupláznak”, jellemzően 2-3 éven belül.

Így az egygyermekes nőkre számolt feltételes görbe azt mutatja, hogy a 2016os adatok szerint nemcsak az első, hanem valójában a második gyermek esetén is szétvált Magyarországon a termékenységi magatartás. Egy, a létszámát tekintve kisebb, de nem elhanyagolható csoportban az első gyermek korai (18-20 éves korban történő) vállalását jó eséllyel gyorsan követi a kistestvér is, míg egy másik tipikus csoport 30 éves kora körül szül először, majd két-három éven belül másodszor.

A két magasabb termékenységű csoport között, illetve több szempontból is demográfia apály alakult ki: egyrészt 21-24 éves életkorban kicsi az első gyermek vállalásának az esélye, aki mégis ebben a korban szül, kisebb eséllyel vállal 
kistestvért néhány éven belül. Másrészt, aki 35 éves vagy annál idősebb korban vállal első gyermeket, már ismét kisebb eséllyel szüli meg második gyermekét.

8. ábra. Az előző szülés óta eltelt idő a második gyermeküket vállaló anyák körében, 2016 The time passed since the last childbirth for mothers taking their second child, 2016

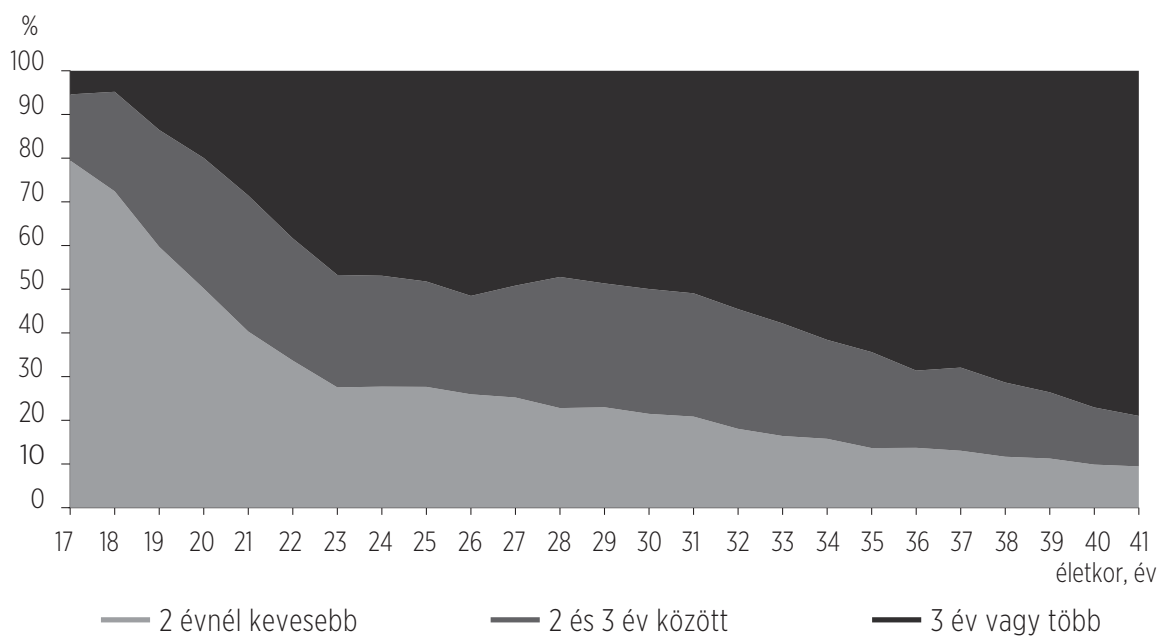

Forrás: KSH, népmozgalmi adatbázis.

A harmadik és többedik gyermekek kapcsán (7.b. ábra) a kép egyértelmübb: a kétgyermekesek további gyermekvállalási kedve fiatal felnőttkorban a legmagasabb, amikor még igen alacsony létszámú és erőteljesen szelektált a kétgyermekes nők csoportja. A harmadik vagy többedik gyermek vállalásának esélye az elmúlt időszakban megfigyelt korspecifikus növekedés ellenére az életkor és így a kockázati sokaság növekedésével és hígulásával párhuzamosan, folyamatosan és egyenletesen csökken, a 30-as életévek elején újabb bimodalitásnak jele nincs.

\section{A termékenységi görbék további tényezők szerinti felbontása: lehetőségek és korlátok}

A témával kapcsolatos szakirodalomban kiemelt helyet kap a paritásonkénti felbontás mellett/helyett más tényezők szerint felbontott termékenységi görbék vizsgálata is. Három fontos tényező játszik itt szerepet: a családi állapot (házas/ nem házas termékenységi görbe), az etnikum/rassz/migráns-nem migráns bontás, illetve az iskolai végzettség. 
Magyarországon a termékenységi görbék etnikum szerinti bontásának vizsgálata egyértelműen indokolt lenne, hiszen a magyarországi roma közösségnek a nem romáktól hangsúlyosan eltérő termékenységi magatartása régóta ismert (Janky 2007, Husz 2011). Emiatt a hazánkban kialakuló bimodalitásnak is magyarázata lehetne egy folyamatosan gyarapodó roma populáció gyermekvállalási kedvének növekedése, amennyiben azt is feltételeznénk, hogy 2011 és 2016 között a romák és a nem romák termékenységének párhuzamos emelkedése úgy következett be, hogy közben a két csoport gyermekvállalási kor szerinti mintái nem közelítettek egymáshoz. (Vagyis a feltételezés szerint a romák és a nem romák gyermekvállalási kedve is nőtt az elmúlt években, de míg a romák esetében ez a korai gyermekvállalás növekedését jelentette volna, addig a nem romáknál ez az emelkedés a 20-as életévek végén következett volna be.) Mindenféle ilyen spekuláció azonban hasztalan, ugyanis a termékenységi görbe etnikum szerinti felbontása Magyarországon nem lehetséges. Bár az alapsokaság etnikum szerinti feloszlása, még ha nagy pontatlansággal is, elvileg becsülhető lenne a népszámlálási és a mikrocenzus-adatbázis alapján, de a népmozgalmi statisztikai adatok nem tartalmaznak etnikai/nemzetiségi változót.

A termékenységi görbe családi állapot szerinti bontása a népesség családi állapot szerinti létező továbbvezetése miatt viszont technikai értelemben elvégezhető. A női népesség kor és gyermekszám szerinti továbbvezetése is elkészül a KSH-ban házas, nem házas bontásban. A magyarországi demográfiai évkönyvek évtizedek óta hagyományosan közlik is az általános, nem paritásspecifikus koréves házas termékenységi arányszámokat. ${ }^{6}$ A gyakorlatban azonban - jelen kutatásban, jelen kutatási kérdés vizsgálatához - ennek nem sok értelmét láttuk, ugyanis egy ilyen felbontásnak valójában akkor lenne értelme, ha a kialakított csoportok egymástól társadalmi vagy demográfiai értelemben elkülönülnének, közöttük különbség volna észlelhető. A jelenlegi magyarországi gyermekvállalási minták esetén azonban a házas és a nem házas sokaság esetén már valójában nem egymástól független, egymással szembeállítható társadalmi/ demográfiai csoportokról van szó. Az első gyermekek házasságon kívüli vállalását ugyanis ma Magyarországon sok esetben házasságkötés követi, és így egyáltalán nem ritka, hogy a második vagy többedik gyermekek már házasságban születnek ugyanazon nő/pár esetén. Ritkább, de szintén jellemző, hogy az esetleges válást követő további párkapcsolatok jellemzően élettársi kapcsolatok, tehát az ilyen kapcsolatokból születő gyermekek jó része szintén nem házasságban születik. A fentiek miatt a példának okáért egy háromgyermekes nő esetén jellemző

${ }^{6}$ Bár kicsit elrejtve, a 4.2.1 táblákban (Élveszületések az anya koréve szerint), találhatóak meg az ezer megfelelő korú házas nöre házasságból jutó élveszületés/nem házas nöre jutó házasságon kívüli élveszületés oszlopok. 
módon előfordulhatna, hogy ugyanazon anya esetén az első és a harmadik gyermek a nem házas, a második pedig a házas termékenységi görbe részeként jelenne meg.

Az iskolai végzettség szerinti felbontásban a családi állapot változások kapcsán felvázolt helyzet ma Magyarországon jóval kevésbé jellemző. Egyfelől a befejezett végzettséget tekintve visszalépés egy életpályán belül nem lehetséges. Másfelől a kurrens szakirodalom szerint (pl. Bartus - Spéder 2016) mindmáig igen ritka az iskolai tanulmányok melletti gyermekvállalás, és az sem gyakori, hogy egy anya a gyermekvállalást követően kezd olyan tanulmányokba, amelyek jelentősen megnövelik a befejezett iskolai végzettségét. (Az ilyen, szülés után végzett tanulmányok jellemzően inkább bővítő, kiegészítő jellegüek: második szakma, második diploma stb.) Emiatt talán nem az ördögtől való, ha követve a bevett társadalomtudományi gyakorlatot a különféle befejezett iskolai végzettségi csoportok közötti átmenettől eltekintünk, és ezeket stabil csoportképző változónak tekintjük. Ugyanakkor egyértelműen figyelni kell arra, hogy az iskolai végzettség szerinti görbéket csak a megfelelő korcsoportokra számoljuk ki, illetve, hogy óvatosan értelmezzük. A következőkben erre teszünk kísérletet.

\section{Az iskolai végzettség szerinti termékenységi görbék}

A termékenységi görbék iskolai végzettség szerinti felbontása Magyarországon a népszámlálások és a mikrocenzusok évében lehetséges, ugyanis ekkor ismerjük meg az alapsokság iskolai végzettség szerinti megoszlását (ld. a tanulmány első részében írottakat).

A 9.a-d. ábrákon a 2001. és 2011. évi népszámlálás, valamint a 2016. évi mikrocenzus adatállománya alapján becsült alapsokasági adatokra vetítjük a népmozgalmi adatgyűjtésből származó születési adatokat, négy összevont iskolai végzettségi csoportra (maximum 8 osztály, szakmunkás végzettség érettségi nélkül, érettségi, felsőfokú végzettség). Noha a két eltérő adatforrás alkalmazása miatt az adatok nem tökéletesen feleltethetők meg egymásnak, mégis megítélésünk szerint ezek egymásra vetítésével képesek vagyunk megfelelő pontossággal megbecsülni az egyes iskolai végzettség szerinti csoportok gyermekvállalási kedvének változását.7 A kapott eredmények jelentős mértékben segítenek megérteni a termékenységi bimodalitás 2011-2016 közötti alakulását.

\footnotetext{
${ }^{7}$ Felmerül a lehetőség, hogy a születési gyakoriságot ne a népmozgalmi statisztikákból, hanem szintén a cenzusokból becsüljük (a cenzus adatbázisokban szereplő maximum 12 hónapos élveszületett gyermekekből). Kontrollként ezt a számítást is elvégeztük, azonban mivel az eredmények érdemben nem tértek el, azokat külön nem közöljük.
} 
9.a-d. ábra. Iskolai végzettség szerinti termékenységi görbék Magyarországon

Unconditional age-specific fertility rates by education in Hungary

\section{A. 8 osztály vagy kevesebb}

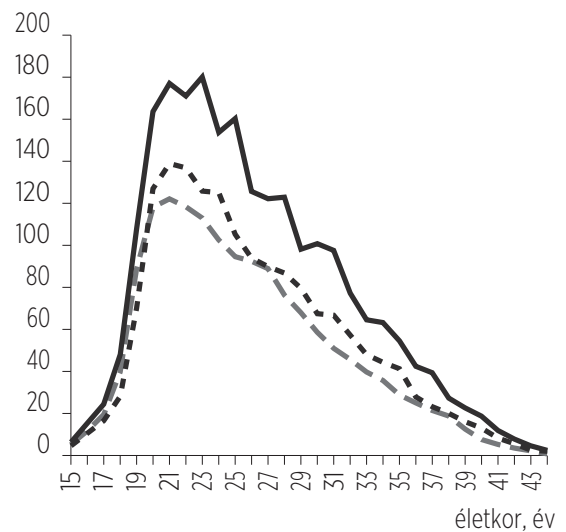

C. Érettségizett

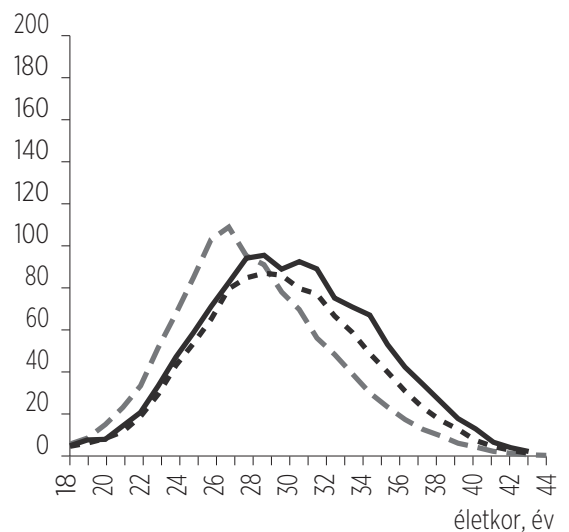

$--2001$

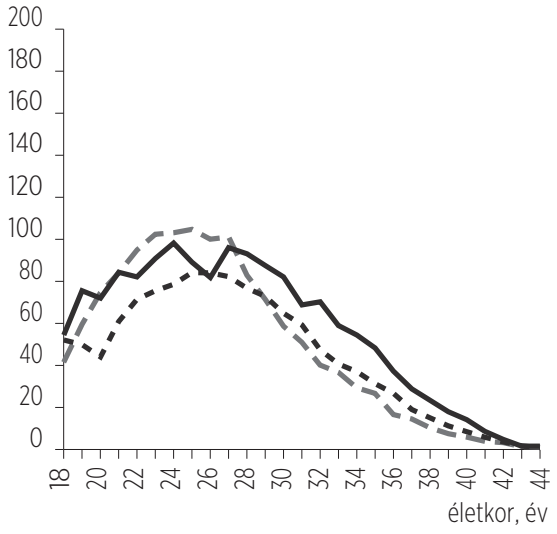

D. Diplomás

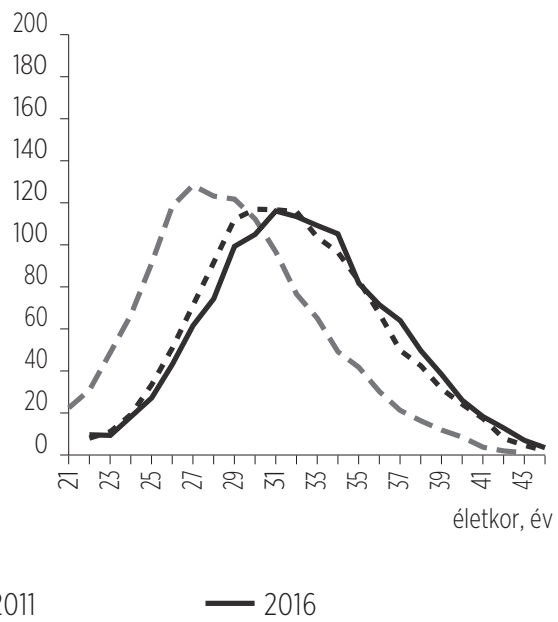

Forrás: KSH-adatok.

Egyfelől megállapítható, hogy 2011 és 2016 között igazán radikális „,babyboom" valójában a 8 osztályt vagy azt sem végzett nők gyermekvállalási kedvét jellemezte. Annak, hogy ez a jelenség a hagyományos keresztmetszeti 
statisztikákban nem jelent meg ilyen látványosan, az volt az oka, hogy ennek a csoportnak a nagysága mindeközben igen gyorsan csökkent: míg a 15-44 éves nők létszáma 683 ezer fő volt 2011-ben, 473 ezer 2011-ben és mindössze 363 ezer fő 2016-ban. Ez utóbbi öt év alatt 23\%-os volt a létszámcsökkenés! Míg 2001 és 2011 között, bár a létszámfogyásnál kisebb mértékben, de mérséklődött az általuk vállalt gyermekek száma, addig 2011 és 2016 között a 23\%-os létszámcsökkenés ellenére a szült gyermekek száma mintegy tizedével még nőtt is. Ez mintegy 37\%-os termékenységnövekedést jelent alig öt év alatt. Ez úgy lehetséges, hogy a nagyobb gyermekvállalási kedv ebben a rétegben egyfelől nem korlátozódott egyes korcsoportokra, de másfelől egyértelműen hangsúlyosabb mértékben volt megfigyelhető fiatal felnőttkorban, gyakorlatilag már 20 éves korra elérve a maximumot, 180\% körüli értékkel.

Az alacsony iskolázottságúak körében a gyermekvállalás teljesen eltérő életkori mintát mutat a magasabb iskolai végzettségű csoportokénál, és ez a „szétfejlődés” látványossá is vált ez elmúlt években. Az adatok arra utalnak, hogy a 2016-os születések esetében a legfeljebb 8 osztályt végzett nőknél az első születések 50\%-a 23 éves kor alatt zajlott le, vagyis a 2016-os trendek szerint a legfeljebb 8 osztályt végzettek többsége 22 éves korára már anya lesz. Öt évvel ezelőtt még ugyanez 23 éves korban, míg az érettségizetteknél (mint majd látni fogjuk) 29-30 évesen következett be. Ez összességében azt jelenti, hogy az alacsony iskolai végzettségü csoportban a gyermekvállalási kedv kor szerinti lefutása jelenleg is hasonló az 1990-es össztársadalmi mintához, csak annál abszolút mértékét tekintve nagyobb. A maximum 8 osztályt végzettek körében tehát lényegében egy a korábbi időszakra jellemző típusú termékenységi görbét, gyermekvállalási mintát követve történt meg egy erőteljes gyermekvállalási kedv növekedés 2011 és 2016 között.

A szakmunkás végzettségü 15-44 éves nők létszáma szintén gyorsan csökken Magyarországon (2001-ben 424 ezer, 2011-ben 334 ezer, 2016-ban 246 ezer fő). Ez nem meglepő, hiszen egyfelől az ezredfordulót követően erőteljesen visszaesett az érettségit nem adó középiskolák népszerüsége, másfelől sokan utólag, a szakképzés megszerzése után le is érettségiztek. A 2000-es évet követő évtizedben a szakmunkások termékenysége valamelyest csökkent, elsősorban a 30 év alattiak körében volt ez megfigyelhető. A 2011-2016-os időszakban, amikor az országos termékenységi kedv is nőtt, egyértelműen nagyobb volt

\footnotetext{
${ }^{8}$ A demográfiai évkönyvek szerint a legfeljebb 8 osztályt végzett anyáknak 2001-ben 26 981, 2011-ben 17 703, 2016-ban pedig 19481 gyermeke született.
} 
a szakmunkás végzettségü nők gyermekvállalási kedve is. Ez a - minden korcsoportban megfigyelhető - növekedés mintegy 26\%-os, az országos átlagot meghaladó volt.

Az érettségizettek esetében fontos a létszámadatok hangsúlyozása, ugyanis ez a legnagyobb, ráadásul viszonylag stabil létszámú csoport az iskolai végzettségi kategóriák közül (2001-ben 742 ezer, 2011-ben 758 ezer, 2016ban 736 ezer fő), így ennek a körnek a gyermekvállalási kedve egyre nagyobb mértékben befolyásolja az országos adatokat. A termékenységi görbék jól mutatják, hogy az érettségizettek között a 2001-es és a 2011-es népszámlálások közötti időszakban erőteljes volt a termékenységi kitolódás. Mivel a 20-as életévekben megfigyelhető termékenységcsökkenést nem tudták ellensúlyozni a 30-as életévekben vállalt „pluszgyermekek”, ehhez ekkor még az összesített gyermekvállalási kedv mérséklődése is társult. 2011 és 2016 között azonban már egyértelmüen, mintegy 16\%-kal nőtt a csoport termékenysége. Ez a növekedés viszont az életkort tekintve teljesen más mintát követ, mint a két alacsonyabb iskolai végzettségű csoporté: a gyermekvállalási kedv növekedése érettségizett nők esetén kizárólag a 27 évesnél idősebbek körében tapasztalható.

A diplomás nők létszámát tekintve egyértelmű és erőteljes a növekedés (270 ezerről 465 ezerre, majd 2016-ban 525 ezerre). Így hiába figyelhető meg az a jelenség, hogy a diplomás anyák által vállalt gyermekek aránya növekvő trendet mutat (pl. mintegy 4\%-kal több gyermeket vállaltak 2016-ban, mint 2011-ben), ha másrészről a csoport létszáma ennél jóval nagyobb (mint láttuk ebben az öt évben több mint 10\%-kal nőtt). A korstruktúra aránytalanságainak kiszürése után azt mondhatjuk, hogy a diplomás nők gyermekvállalási kedve összességében még csökkent is az elmúlt ötéves - egyébként a termékenység növekedésével jellemezhető - időszakban. Az is érdekes tendencia és talán nem független a termékenységcsökkenéstől, hogy míg az ezredfordulón még a felsőfokú végzettségűek jelentős része a diploma megszerzése után, a 20as éveiben vállalt gyermeket, addig ez 2010-re már nem volt jellemző. Így ez a csoport a termékeny életszakasz jelentős részét, több mint felét gyakorlatilag „feláldozza”. Ezt követően viszont hiába magasabb már a gyermekvállalási kedve a diplomásoknak, mint a szakmunkásoké vagy érettségizetteké, ebben az igen rövid termékeny életszakaszban már nem tudják bepótolni azokat a gyermekeket, amelyeket a náluk alacsonyabb iskolai végzettségű társaik már korábban vállaltak. 


\section{MEGBESZÉLÉS/ÉRTEKEZÉS}

Megítélésünk szerint a kétcsúcsú termékenységi görbék kialakulása az adott országok társadalmának tartós vagy ideiglenes demográfiai jellegü polarizációjára vezethető vissza.

Ennek a polarizációnak egyfelöl lehet hagyományos társadalmi oka: az adott országban párhuzamosan egymás mellett élnek különféle, eltérő demográfiai magatartásmintákat követő, egymástól anyagi helyzetük, etnikai származásuk vagy más ok miatt meglehetősen elszigetelt résztársadalmak. Amennyiben az egyik résztársadalomra a korai, a másikra a kései gyermekvállalási minta jellemző, így országos szinten a termékenységi lefutása kétcsúcsúvá fejlődhet. Ebben az esetben a jelenség tartós fennmaradása sem kizárt, amennyiben a két résztársadalom közötti határok egyéb, társadalmi értelemben nem kezdenek el elmosódni, nem következik be integráció.

Másfelől a polarizáció visszavezethető lehet egy egyenlőtlen tempóban lezajló demográfiai, termékenységi átmenetre is. A termékenységi átmenet alatt jellemzően a korai gyermekvállalási minta felől a kései gyermekvállalási minta felé történő eltolódást értjük, tehát azt, hogy a gyermekvállalás átlagos életkora kitolódik. Könnyen lehetséges, hogy egy ilyen folyamat nem egységesen zajlik le egy adott társadalomban. Míg egyes társadalmi csoportok diktálják a trendet, vagy gyorsan adaptálódnak az új mintához, mások esetén a folyamat később indul be. Ebben ez esetben egy átmeneti időszakban párhuzamosan együtt élhet egy korai és egy kései gyermekvállalási minta, amely bimodális termékenységi görbét eredményezhet. Az ilyen esetekben azonban átmeneti jelenségről beszélhetünk. Amint a termékenységi átmenet eléri a „késve induló” társadalmi csoportot, a bimodalitás feloldódik.

Magyarország esetében, amikor észleltük a bimodális termékenységi görbe kialakulását, első pillantásra ez utóbbi, átmeneti bimodalitás tűnik feltételezhetőnek. Ennek azonban egyértelműen ellentmond a jelenség kései kialakulása. Ugyanis 2012-ben, amikor az első gyermek vállalása kapcsán a bimodális termékenységi görbe kialakult, hazánkban a rendszerváltást követő termékenységi kitolódás gyakorlatilag lezárult (Kapitány - Spéder 2015).

A jelenség kialakulása ezért jelenlegi tudásunk szerint inkább egy másik, az előzőnél kisebb jelentőségü hazai demográfiai átalakuláshoz, a 2011 és 2016 között megfigyelhető mintegy 20\%-os termékenységemelkedéshez köthető. A termékenységi görbe paritás és iskolai végzettség szerinti felbontásai arra utalnak, hogy az a termékenységnövekedés Magyarországon társadalmilag erőteljesen polarizáltan ment végbe: egyfelől az alacsony iskolai végzettségi csoportokban 
jelentősen növelte a korai gyermekvállalás esélyét, másfelől a középfokú iskolai végzettségü csoportokban fokozta a 30 év körüliek gyermekvállalás esélyét, illetve a harmadik gyermek vállalásának esélyét, de azt kizárólag idősebb életkorban. A magyarországi 2011-2016-os termékenységnövekedés 2017-2018as kifulladásával egyben feltételezhetően erőteljesen csökken a bimodalitás jelensége is.

Összességében számunkra úgy tünik, hogy a 2012-től kialakuló bimodális termékenységi görbe Magyarországon egy átmeneti, társadalmilag meglehetősen szelektív módon bekövetkezett termékenységnövekedési szakasz egyfajta mellékhatásaként fogható fel. Ha ez a feltételezésünk igaz, akkor ebből az is következik, hogy amennyiben a termékenység szintje a következő években csökkenni fog, feltehetően a bimodalitás is megszünik majd, sőt stagnáló 1,5 körüli termékenység esetén is a jelenség csökkenésével számolhatunk. Amennyiben azonban különféle kormányzati intézkedésekkel a 2016-2018-as stagnálást követően sikerülne újból beindítani egy erőteljes termékenységnövekedést, hasonló hatásmechanizmussal rendelkező ösztönzőket használva, mint a 2011-2016-os időszakban, nem zárható ki a kétcsúcsú termékenységi minta hazai tartós fennmaradása sem. Ebben az esetben viszont a bimodalitás olyan társadalmi-demográfiai polarizációs folyamatokat eredményezhet/jelezhet, amelyek társadalompolitikai szempontból jelentősek lehetnek. 


\section{IRODALOM}

Spéder, Zsolt - Bartus, Tamás 2016: Educational enrolment, double-status positions and the transition to motherhood in Hungary. European Journal of Population, 33(1), 55-85. DOI 10.1007/s10680-016-9394-0

Bermúdez, Silvia - Blanquero, Rafael - Hernández, Juan Antonio - Planelles, Joaquín 2012: A new parametric model for fitting fertility curves. Population Studies, 66(3), 297-310.

Burkimsher, Marion 2017: Evolution of the shape of the fertility curve: Why might some countries develop a bimodal curve? Demographic Research, 37(11), 295-324.

Chandola, Tarani - Coleman, David A. - Hiorns, Robert W. 1999: Recent European fertility patterns: Fitting curves to 'distorted' distributions. Population Studies, 53(3), 317-329.

Husz Ildikó 2011: Alacsony végzettség - sok gyermek? A magas termékenység néhány területi és etnikai aspektusáról Demográfia, 54(1), 5-22.

Janky Béla 2007: A korai gyermekvállalást meghatározó tényezők a cigány nők körében. Demográfia, 50(1), 55-73.

Kapitány Balázs - Spéder Zsolt 2015: Termékenység. In Monostori Judit - Őri Péter Spéder Zsolt (szerk.) 2015: Demográfiai portré 2015. KSH NKI, Budapest, 41-56.

Kapitány Balázs - Spéder Zsolt 2018: Termékenység. In Monostori Judit - Őri Péter Spéder Zsolt (szerk.) 2018: Demográfiai portré 2018. KSH NKI, Budapest, 41-58.

KSH 2013: Népmozgalmi kézikönyv, KSH, Budapest, 129.

KSH 2016: A termékenységi folyamatok hazai jellemzöi, 1970-2015. KSH, Budapest.

Lima, Everton C. - Zeman, Kryštof - Nathan, Mathias - Castro, Ruben - Sobotka, Tomáš. 2017: Twin Peaks: The Emergence of Bimodal Fertility Profiles in Latin America. Working Papers of Vienna Institute of Demography, 10/2017, 25.

Peristera, Paraskevi - Kostaki, Anastasia 2007: Modeling fertility in modern populations. Demographic Research, 16(6), 141-194.

Rendall, Michael - Aracil, Encarnacion - Bagavos, Christos - Couet, Christine - DeRose, Alessandra - DiGiulio, Paola - Lappegard, Trude et al. 2010: Increasingly heterogeneous ages at first birth by education in Southern European and Anglo-American familypolicy regimes: A seven-country comparison by birth cohort. Population Studies, 64(3), 209-227.

Sullivan, Rachel 2005: The age pattern of first-birth rates among US women: The bimodal 1990s. Demography, 42(2), 259-273.

Tekse Kálmán 1965: Korspecifikus születési arányszámok demográfiai modelljeiről. Demográfia, 8(2), 201-219.

Vukovich György 1969: A termékenységi görbe és a születésszám (Néhány gyakorlati probléma). Demográfia, 12(1-2), 65-71. 


\section{BIMODAL FERTILITY CURVE IN HUNGARY: DESCRIPTIVE RESULTS AND POSSIBLE CAUSES}

\section{ABSTRACT}

The examination of the temporal formation of fertility and the patterns and changes of the fertility curve has been a classic subject of demography for decades in Hungary too. It is known from the scientific literature that, in some rare, special cases - typically in a transitional period in a society - a fertility curve with two peaks occurs. This is the so-called bimodal fertility curve. The recent Hungarian data suggests that this bimodal fertility curve has developed in Hungary in the last half decade. Because of the potential social and population policy significance of this phenomenon, it seems for us important to review the literature of the bimodal fertility curve and examine the current Hungarian fertility data in details. According to our results, the bimodality in Hungary may be a side effect of the fertility growth in the last half decade, wich growth was - in certain respects - very selective in Hungary. 